\title{
Analisis dan Perancangan Sistem Informasi Persedian dan Penjualan pada PT Alfa Gema Khatulistiwa Jaya Menggunakan Metode Analisis PIECES
}

\author{
Doni $^{{ }^{*}}$ \\ ${ }^{1}$ Program Studi Sistem Informasi Universitas Widya Dharma Pontianak \\ *doni@widyadharma.ac.id
}

\begin{abstract}
In supporting business activities, PT Alfa Gema Khatulistiwa Jaya has implemented a semi-computerized system. Sales transactions made by employees still use notes created manually, these notes must be kept by the customer. because these notes are used for the accumulation of bonus calculations given by PT Alfa Gema Khatulistiwa Jaya. Meanwhile, computers are used to process product sales data using Microsoft Excel applications. with the existing sales and inventory system, service to customers is not excellent. The purpose of the authors of this research is to produce an information system design for inventory and sales of goods that can be easily operated, improve service to customers and facilitate the company in processing inventory data. The author uses descriptive research methods in this study. The author collected data using observation, interviews, and literature study. The author uses the UML (Unified Modeling Language) modeling technique and uses Microsoft Visual Fox Pro 9.0 in system design techniques and uses the PIECES Analysis Method.
\end{abstract}

Keywords: design, sales information system, PIECES analysis

\begin{abstract}
Abstrak
Dalam menunjang kegiatan bisnis, PT Alfa Gema Khatulistiwa Jaya telah menerapkan sistem semi terkomputerisasi. Transaksi penjualan yang dilakukan oleh karyawan masih menggunakan nota yang dibuat secara manual, nota tersebut harus disimpan oleh pelanggan, karena nota tersebut digunakan untuk akumulasi perhitungan bonus yang diberikan PT Alfa Gema Khatulistiwa Jaya. Sedangkan komputer digunakan untuk melakukan pengolahan data penjualan produk dengan menggunakan aplikasi Microsoft Excel. dengan sistem penjualan dan persediaan yang ada membuat pelayanan kepada pelanggan tidak prima. Tujuan penulis melakukan penelitian ini adalah untuk menghasilkan suatu rancangan sistem informasi persediaan dan penjualan barang yang dapat dengan mudah dioperasikan, meningkatkan pelayanan terhadap pelanggan dan mempermudah pihak perusahaan dalam pengolahan data inventorinya. Penulis menggunakan metode penelitian deskriptif pada penelitian ini. Penulis mengumpulkan data dengan cara observasi, wawancara dan studi pustaka. Penulis menggunakan teknik pemodelan UML (Unified Modelling Language) dan menggunakan Microsoft Visual Fox Pro 9.0 dalam teknik perancangan sistem serta menggunakan Metode Analisis PIECES.
\end{abstract}

Kata kunci: perancangan, sistem informasi penjualan, analisis PIECES

\section{Pendahuluan}

Sistem informasi pada era revolusi industri 4.0 memegang peranan penting untuk meningkatkan kinerja sebuah perusahaan ataupun bidang organisasi lainnya seperti bidang pendidikan, bidang kesehatan dan bidang organisasi lainnya. Penerapan sistem informasi dapat dilakukan terutama dalam kegiatan manajemen data dari sebuah organisasi, karena data dapat berubah sewaktu-waktu dengan perubahan data yang banyak dan besar. Perubahan data tersebut harus disimpan dan diolah dengan baik agar menghasilkan sebuah informasi yang akurat, relevan dan tepat waktu bagi organisasi.

Kesadaran akan pengaruh teknologi komputer yang semakin besar serta dapat meningkatkan kinerja bisnis perusahan sangat berdampak positif bagi sebuah organisasi. Hal ini akan menuntut organisasi untuk mulai membenahi sistem yang ada di dalam organisasi dengan menerapkan sistem yang 
terkomputerisasi. Sistem komputerisasi pada sebuah organisasi yang bertujuan untuk kegiatan manajemen data dalam organisasi harus dikembangkan melalui tahap pengembangan sistem agar tingkat ketelitian pengolahan data semakin tinggi. Dengan adanya komputerisasi pada sistem penjualan, tingkat pelayanan kepada pelanggan akan lebih baik karena beberapa proses akan berlangsung secara otomatis. Hal ini akan berdampak langsung pada omzet perusahaan serta pengolahan data yang lebih akurat dan cepat bagi perusahaan. Sedangkan sistem terkomputerisasi pada bagian persediaan dapat meningkatkan pengendalian stok yang lebih baik sehingga dapat mengurangi biaya pembelian terhadap produk yang masih banyak serta terhadap produk yang tingkat sirkulasi pengeluarannya agak lamban.

PT Alfa Gema Khatulistiwa Jaya adalah perusahaan yang bergerak dalam bidang penjualan produk secara langsung, memiliki pesaing bisnis tunggal dalam menjalankan kegiatan bisnisnya. Pesaing tunggal tersebut dalam menjalankan kegiatan bisnisnya sudah menerapkan sistem terkomputerisasi sehingga pelayanan yang ditawarkan kepada pelanggan lebih prima serta informasi yang diinginkan oleh pelanggan dapat diperoleh dengan cepat. Hal ini tentunya akan menghambat pertumbuhan bisnis yang dijalankan oleh PT Alfa Gema Khatulistiwa Jaya untuk berkembang lebih pesat serta memperluas jaringan penjualan kepada masyarakat yang ada di Kalimantan Barat ini. Perusahaan harus melihat dan mengevaluasi hambatan bisnis yang muncul dari pesaing sejenis serta harus lebih tanggap terhadap perkembangan teknologi yang semakin berkembang pesat setiap saatnya. Penyediaan informasi yang up to date kepada pelanggan oleh perusahaan pesaing ini harus dijadikan bahan pertimbangan bagi PT Alfa Gema Khatulistiwa Jaya untuk lebih cepat mengambil langkah dalam memperbaiki sistem berjalan saat ini.

\section{Metoda Penelitian}

Menurut [1], "Data adalah deskripsi tentang benda, kejadian, aktivitas dan transaksi yang tidak mempunyai makna atau tidak berpengaruh secara langsung kepada pemakai".

Menurut [1], "Informasi merupakan salah satu sumber daya penting dalam suatu organisasi, digunakan sebagai bahan pengambil keputusan".

Menurut [2], "Sistem informasi merupakan kumpulan dari perangkat keras dan perangkat lunak komputer serta perangkat manusia yang akan mengolah data menggunakan perangkat keras dan perangkat lunak tersebut".

Menurut [3], "Yang dimaksud dengan sistem analisis dan desain adalah peningkatan kinerja suatu organisasi dengan tujuan perbaikan prosedur-prosedur dan metode yang lebih baik".

Menurut [4], "Perancangan sistem adalah penentuan proses dan data yang diperlukan oleh sistem baru".

Analisis PIECES (Performance, Information, Economy, control, Eficiency, dan Service) merupakan teknik untuk mengidentifikasi dan memecahkan permasalahan yang terjadi pada sistem informasi. Dari analisis ini akan menghasilkan identifikasi masalah utama dari suatu sistem serta memberikan solusi dari permasalahan tersebut. [5]

Menurut [6], "Unified Modelling Language (UML) adalah sebuah "bahasa" yang telah menjadi standar dalam industri untuk visualisasi, merancang dan mendokumentasi sistem piranti lunak".

\section{Hasil Penelitian}

\subsection{Analisis PIECES}

Metode analisis PIECES digunakan untuk memperoleh pokok-pokok permasalahan yang lebih spesifik dalam sebuah organisasi. Analisis ini sangat penting dilakukan sebelum organisasi memutuskan untuk mengembangkan sebuah sistem informasi agar lebih mengetahui permasalahan yang dihadapi. 
Tabel 1. Analisis PIECES PT Alfa Gema

Khatulistiwa Jaya

\begin{tabular}{|c|c|c|}
\hline $\begin{array}{c}\text { Jenis } \\
\text { Analisis }\end{array}$ & $\begin{array}{c}\text { Kelemahan } \\
\text { Sistem Lama }\end{array}$ & $\begin{array}{c}\text { Sistem yang } \\
\text { Diajukan }\end{array}$ \\
\hline Performance & $\begin{array}{l}\text { Sistem penjualan } \\
\text { dan persediaan semi } \\
\text { terkomputerisasi } \\
\text { menghambat } \\
\text { transaksi penjualan } \\
\text { dan retur penjualan. }\end{array}$ & $\begin{array}{l}\text { Sistem } \\
\text { terkomputerisasi } \\
\text { yang menangani } \\
\text { transaksi } \\
\text { penjualan secara } \\
\text { terkomputerisasi. }\end{array}$ \\
\hline Information & $\begin{array}{l}\text { Sistem persedian } \\
\text { manual yang } \\
\text { menyebabkan } \\
\text { proses informasi } \\
\text { berlangsung lama } \\
\text { dan tidak akurat. }\end{array}$ & $\begin{array}{l}\text { Sistem informasi } \\
\text { persediaan } \\
\text { terintegrasi } \\
\text { dengan sistem } \\
\text { penjualan. }\end{array}$ \\
\hline Economic & $\begin{array}{lr}\text { Dibutuhkan } & \text { banyak } \\
\text { karyawan untuk } & \\
\text { pengecekan } & \\
\text { ketersedian produk } \\
\text { saat transaksi } \\
\text { penjualan. }\end{array}$ & $\begin{array}{l}\text { Dalam jangka } \\
\text { panjang } \\
\text { membutuhkan } \\
\text { biaya untuk } \\
\text { pengadaan sistem } \\
\text { informasi. Namun } \\
\text { dalam jangka } \\
\text { panjang lebih } \\
\text { sedikit biaya yang } \\
\text { dikeluarkan. }\end{array}$ \\
\hline Control & $\begin{array}{l}\text { Sulit mengontrol } \\
\text { stok produk yang } \\
\text { tersedia. }\end{array}$ & $\begin{array}{lr}\text { Dengan } & \text { sistem } \\
\text { persedian, } & \text { stok } \\
\text { keluar dan } & \text { masuk } \\
\text { lebih } & \text { mudah } \\
\text { dikontrol } & \end{array}$ \\
\hline Eficiency & $\begin{array}{lr}\text { Waktu } & \text { yang } \\
\text { dibutuhkan } & \text { untuk } \\
\text { setiap } & \text { transaksi } \\
\text { penjualan } & \text { lebih } \\
\text { panjang } & \text { karena } \\
\text { harus } & \text { mencari } \\
\text { informasi } & \\
\text { ketersedian. } & \end{array}$ & $\begin{array}{l}\text { Dengan sistem } \\
\text { penjualan dan } \\
\text { persediaan } \\
\text { terkomputerisasi } \\
\text { meningkatkan } \\
\text { efisiensi setiap } \\
\text { kali transaksi } \\
\text { yang dilakukan. }\end{array}$ \\
\hline Services & $\begin{array}{l}\text { Pelayanan kepada } \\
\text { pelanggan menjadi } \\
\text { tidak maksimal, } \\
\text { karena informasi } \\
\text { yang diberikan tidak } \\
\text { relevan, akurat dan } \\
\text { tepat waktu. }\end{array}$ & $\begin{array}{l}\text { Pelayanan yang } \\
\text { diberikan akan } \\
\text { lebih maksimal } \\
\text { karena informasi } \\
\text { ketersedian } \\
\text { sebuah produk } \\
\text { dapat langsung } \\
\text { dicek pada } \\
\text { komputer yang } \\
\text { tersedia. }\end{array}$ \\
\hline
\end{tabular}

\subsection{Gambaran Umum Sistem Berjalan}

Pada alur kegiatan berjalan, kegiatan penjualan digambarkan menggunakan bentuk use case diagram sebagai berikut:

1. Proses pembelian dilakukan oleh pimpinanan berdasarkan kebutuhan penjualan. Pertimbangan ini berdasarkan laporan penjualan yang diterima dari bagian keuangan.

2. Dari petugas penjualan akan memberikan informasi produk kepada pelanggan, melakukan pengecekan produk sampai dengan proses transaksi penjualan yang diakhiri dengan pembuatan nota penjualan oleh petugas penjualan.

3. Bagian gudang akan memberikan barang yang diminta bagian penjualan serta bagian gudang akan mencatat semua kegiatan keluar masuk barang. Bagian gudang akan menyiapkan laporan stok barang tersedia di gudang.

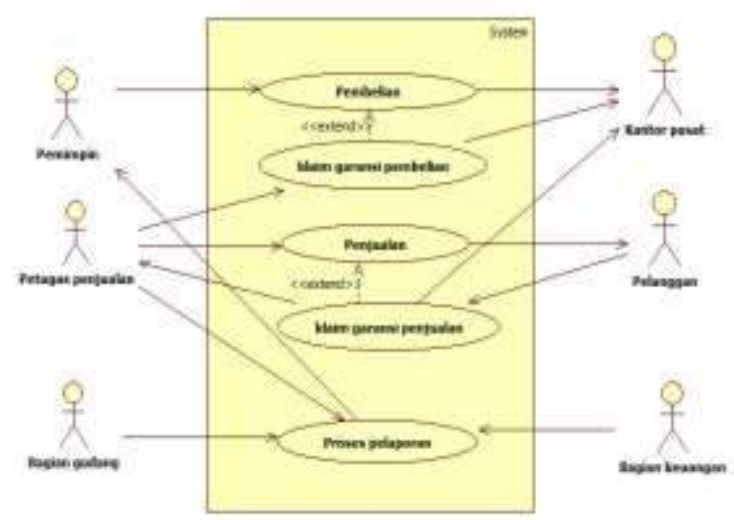

Gambar 1. Use Case Sistem Berjalan

\subsection{Rancangan Sistem Usulan}

Setelah melakukan analisis terhadap sistem berjalan pada PT Alfa Gema Khatulistiwa Jaya dapat disimpulkan bahwa sistem yang diterapkan selama ini masih belum berjalan sesuai harapan perusahaan. Hal ini disebabkan karena belum optimalnya penyediaan informasi yang cepat dan tepat bagi pelanggan maupun pemimpin. Dampak dari hal ini adalah ketidakpuasan pelanggan terhadap pelayanan yang diberikan sehingga perusahaan dianggap tidak bisa menyediakan pelayanan yang prima untuk pelanggan.

Sistem informasi persediaan dan penjualan yang diusulkan kepada perusahaan merupakan perubahan prosedur yang sedang berjalan pada PT Alfa Gema Khatulistiwa Jaya dengan menerapkan sistem informasi yang berbasis komputerisasi. Sistem yang diusulkan diharapkan dapat mengatasi permasalahan yang selama ini dihadapi oleh perusahaan yaitu untuk mengendalikan persediaan dan penjualan barang yang terjadi di dalam kegiatan bisnis perusahaan.

Diagram use case akan menggambarkan fungsionalitas dari sistem persediaan dan penjualan berbasis komputerisasi yang penulis usulkan. Adapun proses sistem usulan sebagai berikut: 


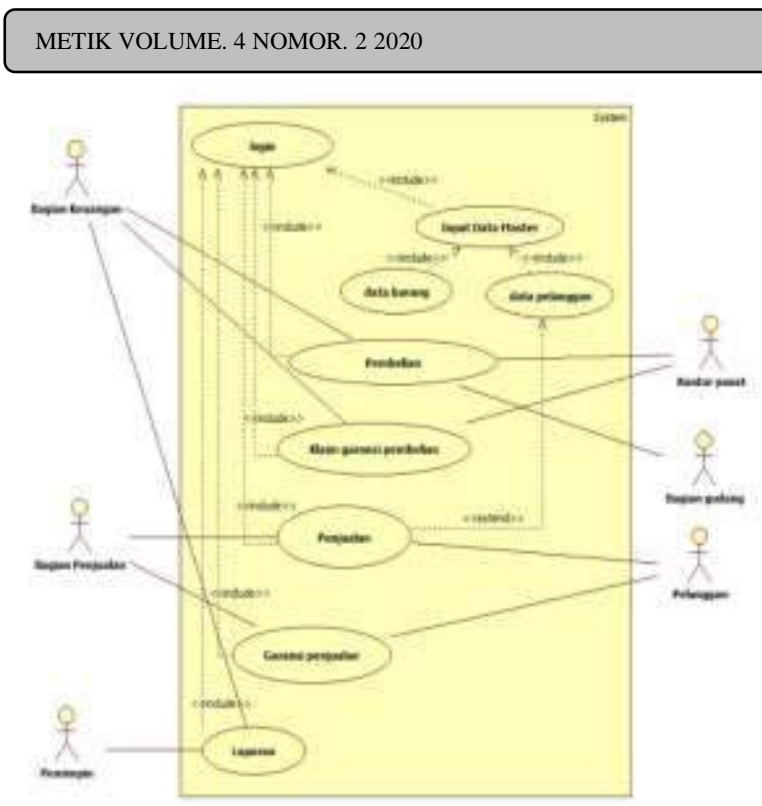

Gambar 2. Use Case Sistem Usulan

Alur sistem usulan untuk PT Alfa Gema

Khatulistiwa Jaya:

1. Bagian keuangan akan melakukan proses login pada sistem untuk menginputkan barang yang akan dibeli melalui proses pembelian.

2. Bagian gudang akan melakukan proses pengecekan barang yang dikirm kantor pusat.

3. Barang yang rusak pada proses pengiriman dari kantor pusat akan mendapatkan klaim garansi pembelian dari kantor pusat yang dilakukan oleh bagian keuangan.

4. Proses penjualan terjadi antara bagian penjualan dengan pelanggan. sebelum melakukan penjualan, bagian penjualan akan meminta kartu anggota kepada pelanggan.

5. Bagian penjualan akan menerima orderan dari pelanggan dan Bagian penjualan akan menginputkan orderan tersebut ke dalam komputer. Apabila barang yang diorder tidak tersedia maka sistem yang dirancang penulis akan memberikan informasi secara cepat sehingga dapat menangani proses penjual dengan efektif.

6. Proses klaim garansi penjualan yang dilakukan oleh pelanggan kepada bagian penjualan. Bagian penjualan dapat mengetahui informasi ketersediaan barang melalui komputer yang berisi aplikasi persediaan yang penulis rancang sehingga memudahkan proses klaim garansi penjualan.
7. Semua laporan dapat di akses oleh pemimpin perusahaan melalui sistem yang penulis rancang. Laporan juga disediakan oleh bagian keuangan kepada pemimpin, laporan yang diberikan adalah laporan yang telah dilakukan proses pemeriksaan lebih lanjut.

Proses penjualan yang diusulkan penulis pada sistem usulan dapat dijelaskan sebagai berikut:

1. Pelanggan akan mengorder barang kepada petugas penjualan.

2. Petugas penjualan akan memasukkan data barang yang diorder pelanggan apabila barang yang diorder tersebut tidak tersedia di gudang maka sistem secara otomatis akan memberikan informasi kepada petugas penjualan sehingga petugas penjualan dapat dengan cepat menberikan informasi ketersedian barang. Hal ini tentunya sangat efektif sekali daripada cara mengecek ketersediaan barang yang terjadi pada sistem berjalan.

3. Setelah semua transaksi pembayaran dilakukan oleh pelanggan dan bagian penjualan maka data penjualan tersebut akan disimpan dalam simpanan data penjualan yang dapat digunakan sebagai proses pelaporan.

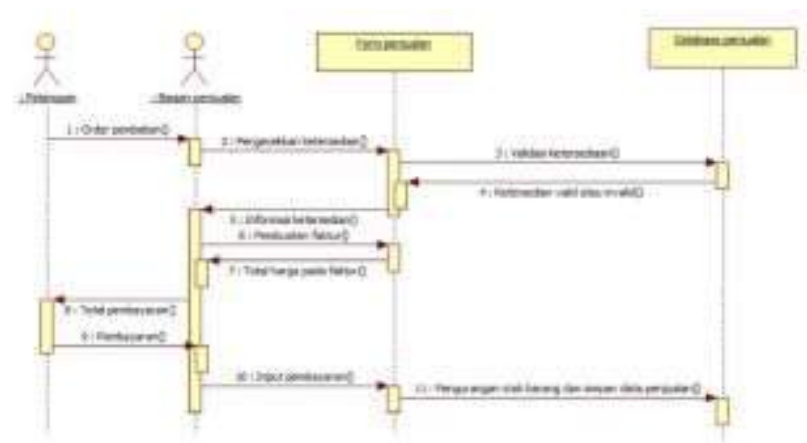

Gambar 3. Sequence Diagram Penjualan

\subsection{Rancangan Input}

Rancangan layar input untuk sistem informasi persediaan dan penjualan pada PT Alfa Gema Khatulistiwa Jaya adalah sebagai berikut: 


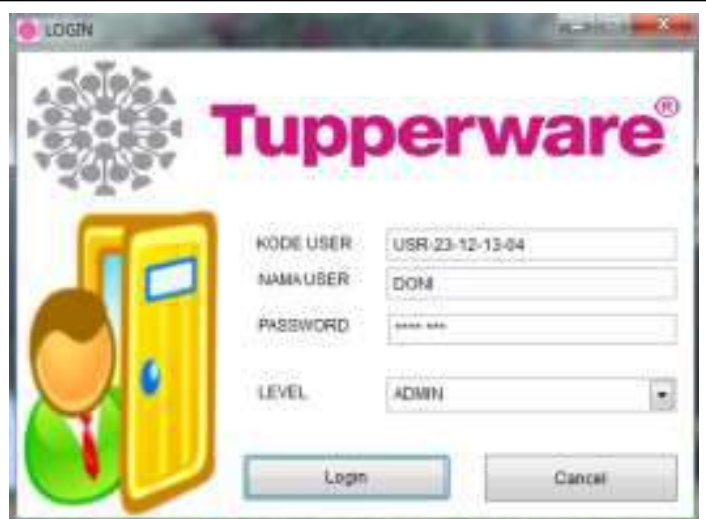

Gambar 4. Tampilan Form Login

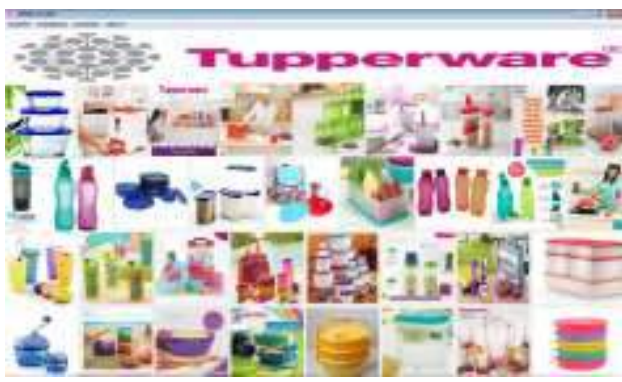

Gambar 5. Tampilan Menu Utama

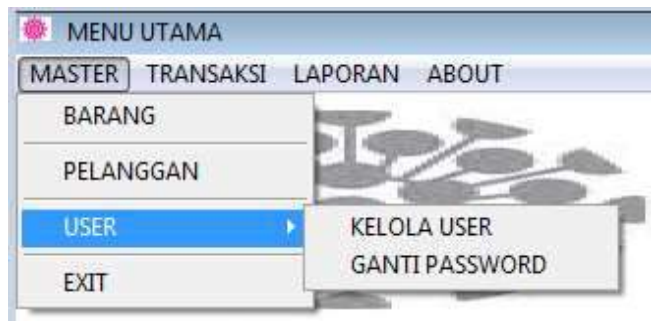

Gambar 6. Tampilan Menu Master

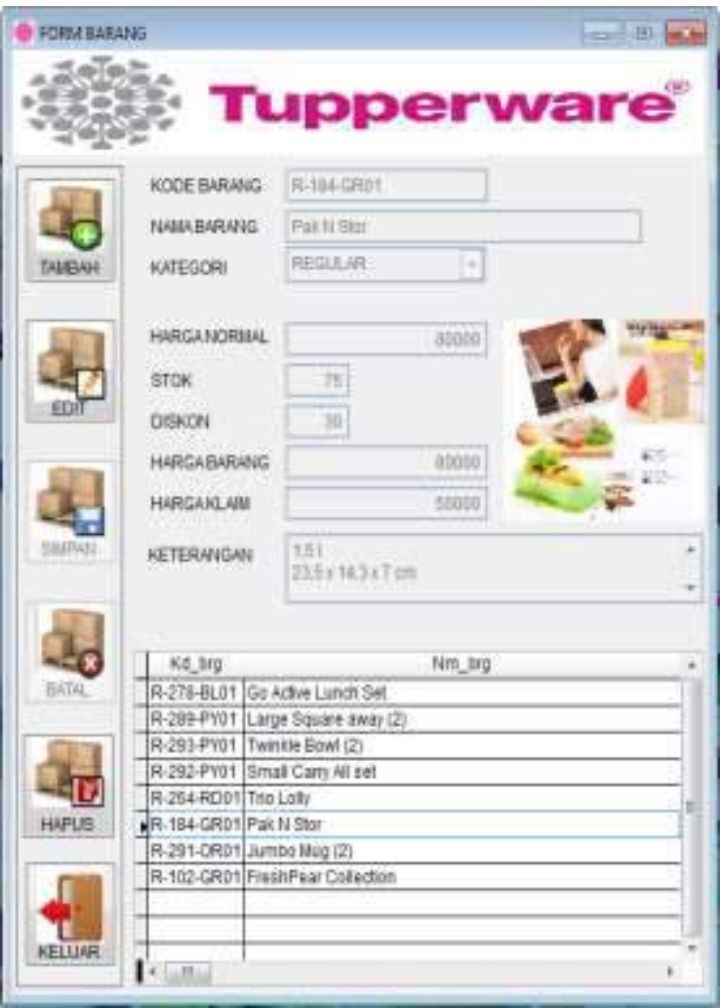

Gambar 7. Tampilan Form Barang

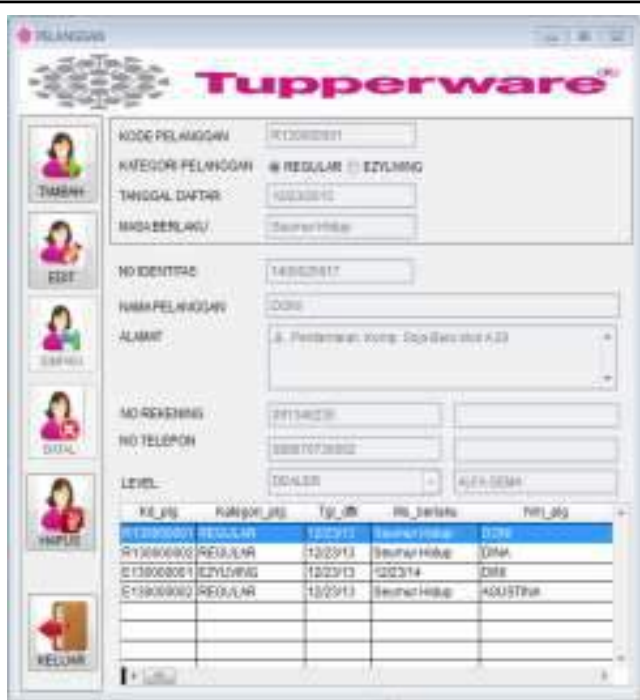

Gambar 8. Tampilan Form Pelanggan

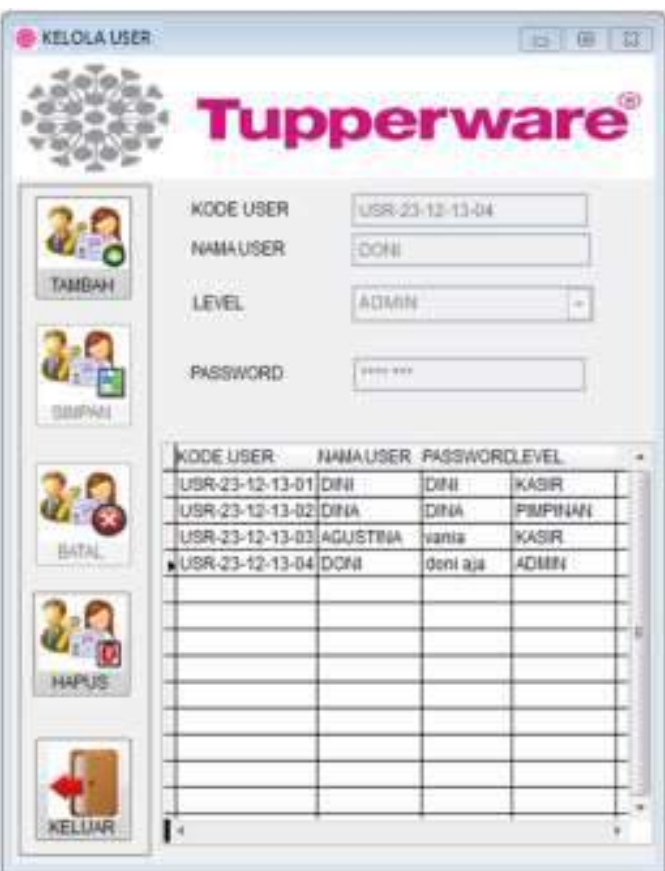

Gambar 9. Tampilan Form Kelola User

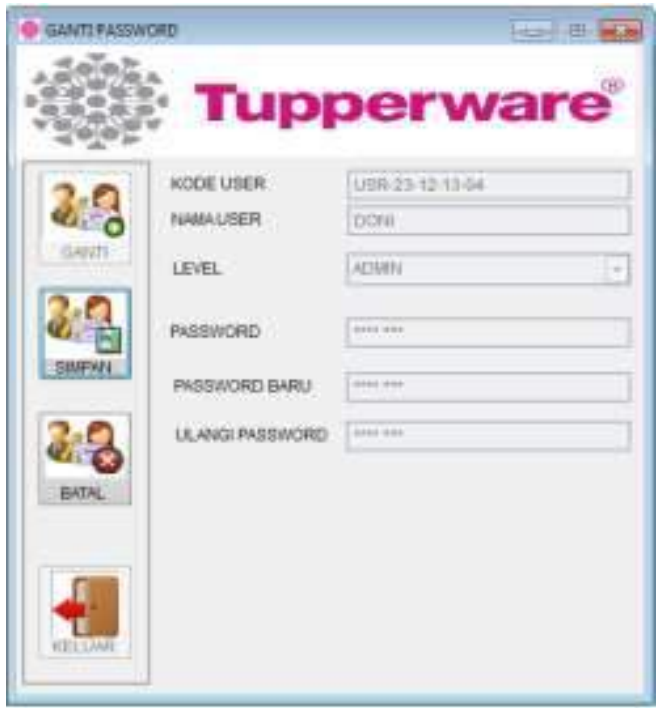

Gambar 10. Tampilan Form Ganti Password 


MENU UTAMA
MASTER TRANSAKSI LAPORAN ABOUT
$\begin{aligned} & \text { PEMBELIAN } \\ & \text { PENJUALAN } \\ & \text { KLAIM GARANSI PEMBELIAN } \\ & \text { KLAIM GARANSI PENJUALAN } \\ & \text { VOUCHER GARANSI }\end{aligned}$

Gambar 11. Tampilan Menu Transaksi

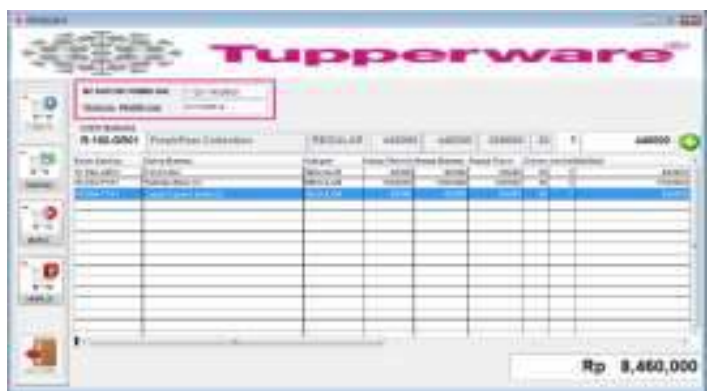

Gambar 12. Tampilan Form Pembelian

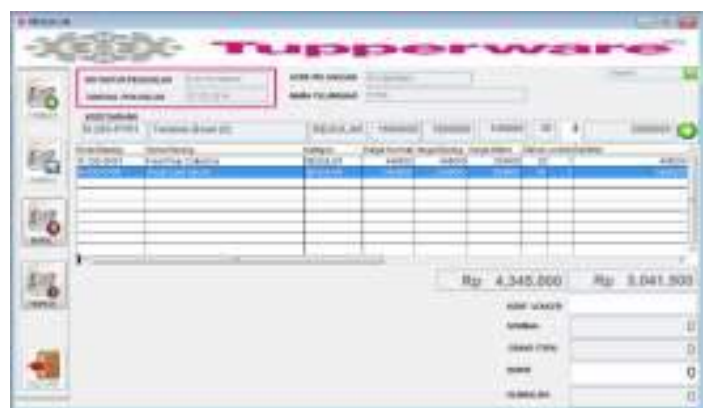

Gambar 13. Tampilan Form Penjualan

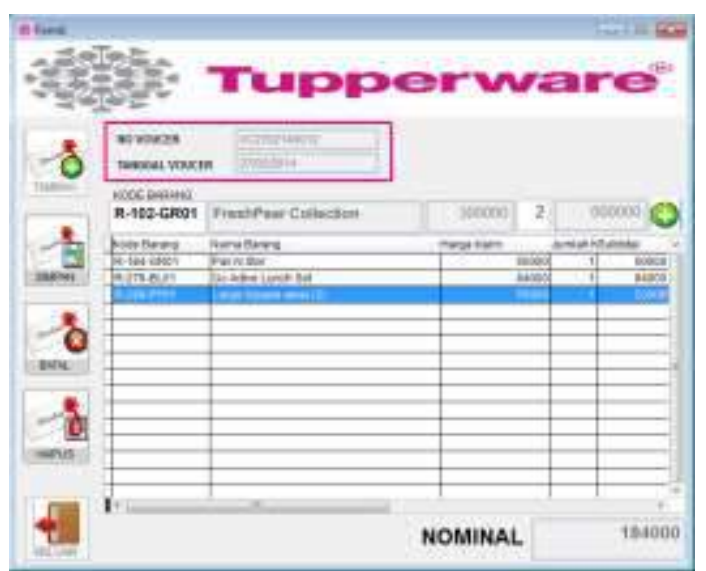

Gambar 14. Tampilan Form Voucher Garansi

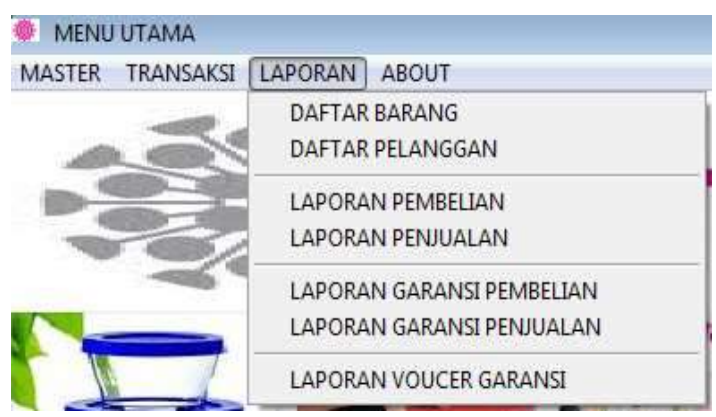

Gambar 15. Tampilan Menu Laporan

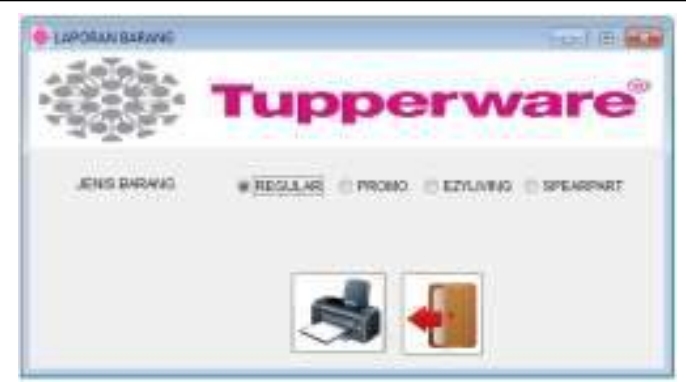

Gambar 16. Tampilan Form Laporan Barang

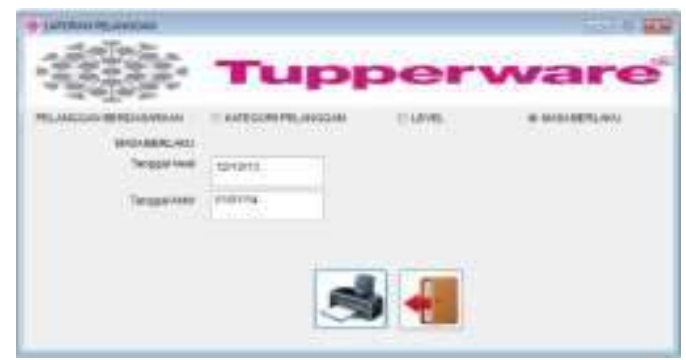

Gambar 17. Tampilan Form Laporan Pelanggan

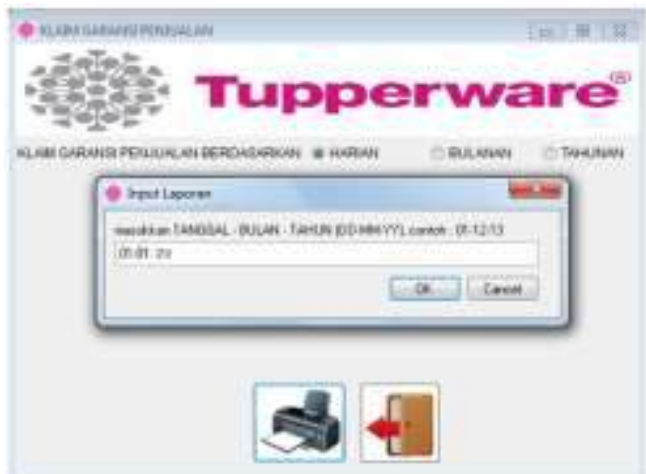

Gambar 18. Tampilan Form Laporan Penjualan

\subsection{Rancangan Output}

Rancangan output untuk sistem informasi persediaan dan penjualan pada PT Alfa Gema Khatulistiwa Jaya adalah sebagai berikut:

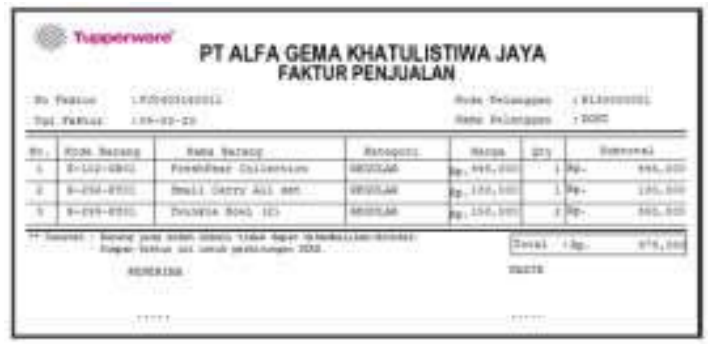

Gambar 19. Tampilan Faktur Penjualan

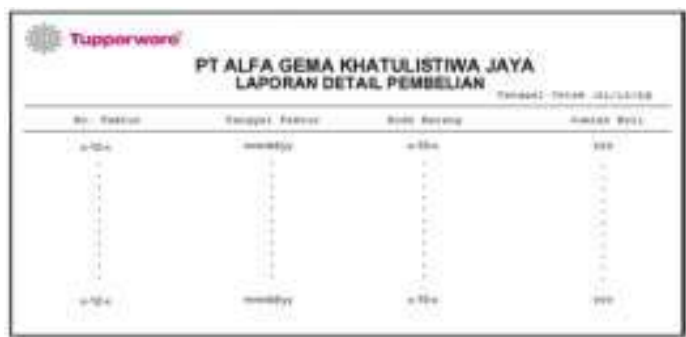

Gambar 20. Rancangan Detail Pembelian 


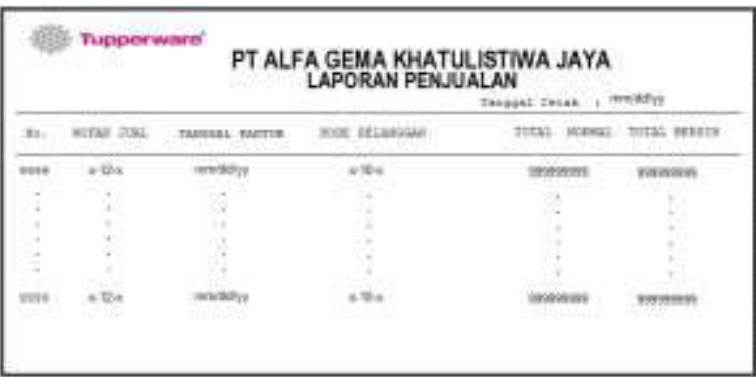

Gambar 21. Rancangan Laporan Penjualan

\section{Kesimpulan}

Sistem informasi persediaan dan penjualan pada PT Alfa Gema Khatulistiwa Jaya selama ini masih dilakukan semi terkomputerisasi, hal ini dapat menghambat kegiatan bisnis yang terjadi pada PT Alfa Gema Khatulistiwa Jaya karena informasi yang disediakan tidak tepat waktu.

Dengan adanya sistem informasi persedian dan penjualan ini, diharapkan pihak perusahaan dapat lebih mudah menyajikan informasi tentang persedian lebih cepat dan akurat, penyimpanan data yang lebih efisien serta proses pelaporan yang lebih cepat sehingga mendukung pimpinan dalam mengambil keputusan dalam mencapai tujuan bisnis PT Alfa Gema Khatulistiwa Jaya.

\section{Saran}

Perlunya penambahan peralatan komputer dalam penerapan sistem informasi persediaan dan penjualan yang penulis rancang, karena peralatan komputer yang dimilik perusahaan saat ini tidak mendukung penerapan sistem yang penulis rancang.

Perlunya pelatihan terhadap sumber daya manusia yang ada pada perusahaan, karena selama ini sumber daya manusia yang ada pada perusahaan belum terbisa menggunakan komputer dalam menjalankan kegiatan bisnis perusahaan.

Sistem informasi persediaan dan penjualan harus selalu di-update sesuai dengan perkembangan teknologi di masa yang akan datang yang berkembang sesuai perkembangan zaman menjadi semakin canggih.

\section{Daftar Pustaka}

[1] Kadir, Abdul, dan Terra Ch. Triwahyuni "Pengenalan Teknologi Informasi," Penerbit ANDI, Yogyakarta, 2009.

[2] Kristanto, Andri, "Perancangan Sistem Informasi dan Aplikasinya," Gava Media, Yogyakarta, 2018.

[3] Simarmata, Janner, "Pengenalan Teknologi Komputer dan Informasi," Penerbit ANDI, Yogyakarta, 2009.

[4] Sutabri, Tata, "Analisa Sistem Informasi," Penerbit ANDI, Yogyakarta, 2009.

[5] Maslahah, Khoirul, "Analisis Sistem Informasi Perpustakaan IAIN Surakarta dengan PIECES," EduLib., vol. 1, no. 1, pp. 127-140, 2011.

[6] Sugiarti, "Analisis Dan Perancangan Sistem Informasi Dengan Metodologi Berorientasi Objek," Informatika, Bandung, 2013. 